\title{
Genetic Diversity Studies on Parental and Interspecific Hybrids (Gossypium hirsutum L. × Gossypium barbadense L.) of Cotton
}

\author{
S. Malathi ${ }^{i^{*}}$ and Rajesh S. Patil ${ }^{2}$ \\ ${ }^{1}$ College of Agriculture, Dharwad, ${ }^{2}$ Agriculture Research Station, Dharwad Farm, University \\ of Agricultural Sciences, Dharwad, India \\ *Corresponding author
}

A B S T R A C T

\begin{tabular}{|c|c|}
\hline $\begin{array}{l}\text { Ke y w o r d s } \\
\text { Genetic diversity, } \\
\text { Mahalanobis D2 } \\
\text { statistic, Cluster, } \\
\text { and Triple cross } \\
\text { hybrids }\end{array}$ & $\begin{array}{l}\text { Genetic diversity analysis was conducted at Main Agricultural Research Station, } \\
\text { University of Agricultural Sciences, Dharwad during Kharif, 2017. In this study, } 35 \\
\text { genotypes were evaluated for } 11 \text { yield and yield attributing traits and grouped into four } \\
\text { clusters through Mahalanobis } \mathrm{D}^{2} \text { statistic. Cluster I was the biggest with } 23 \text { genotypes } \\
\text { followed by cluster II, III and IV. Among eleven characters studied, seed cotton yield } \\
(25.38 \%) \text { and days to } 50 \text { per cent flowering }(22.86 \%) \text {, contributed high for divergence }\end{array}$ \\
\hline Article Info & \\
\hline $\begin{array}{l}\text { Accepted: } \\
\text { 04 March } 2019 \\
\text { Available Online: } \\
10 \text { April } 2019\end{array}$ & $\begin{array}{l}\text { genotype secured } 1 \text { st rank with an overall score of } 20 \text { across } 13 \text { characters and the cluster } \\
\text { III obtained } 4 \text { th rank with an overall score of } 34 \text {. As high inter-cluster distance is shown by } \\
\text { cluster III and IV, hence is desirable to select genotypes from these clusters to develop } \\
\text { triple cross hybrids for further crop improvement programs. }\end{array}$ \\
\hline
\end{tabular}

\section{Introduction}

Cotton the king of fibre reside one of the momentous and important cash crop exercising profound influence on economics and social affairs of the world. The word "cotton" derived from the Arabic word "al qatan" and popularly known as "White Gold". Cotton plays vital role in Indian economy as it is the backbone of textile industry. The Gossypium species were domesticated in both the old and new world. It supplies products such as lint, oil, seed meal, hulls and linters. The genus Gossypium, a member of the Malvaceae family, consists of 50 species, four of which are generally cultivated species. Out of the four cultivated species, Gossypium hirsutum L. and Gossypium barbadense L. are tetraploids $(2 \mathrm{n}=4 \mathrm{x}=52)$ and are commonly called as new world cottons. Whereas, Gossypium arboreum L. and Gossypium herbaceum L. are diploids $(2 \mathrm{n}=2 \mathrm{x}=26)$ and known as old world cottons. India is the only country, where all four cultivated species of cotton viz., G. herbaceum, G. arboreum, $G$. hirsutum and G. barbadense are grown. In India, the crop is being grown in area of 12.3 million hectares, producing 28.50 million bales with a productivity of $504 \mathrm{~kg} \mathrm{ha}^{-1}$. In Karnataka, cotton is being grown in area of 
5.65 lakh hectares with production and productivity of 19.0 lakh bales and $572 \mathrm{~kg}$ $\mathrm{ha}^{-1}$ respectively (Anon., 2018). For an outstanding breeding program in the crop improvement, diversity analysis greatly helps the breeder in the identification and proper choice of parents for specific breeding objectives. The present study was to assess the genetic diversity among genotypes of cotton.

\section{Materials and Methods}

The experimental material consisted of 35 genotypes comprising of eight lines, three testers (Table 1) and their resultant twenty four hybrids produced by line $\mathrm{x}$ tester mating design. The experimental material was sown in Randomised Block Design with three replications during Kharif, 2017-18 at Agricultural Research Station Dharwad. Three rows of each $4.2 \mathrm{~m}$ length was assigned to each genotype with plants having $60 \mathrm{~cm}$ intra spacing and $90 \mathrm{~cm}$ inter row spacing.

Five plants were randomly selected from each replication for each genotype and the average value for each plot was computed for plant height, number of monopodia, number of sympodia, boll weight, number of bolls per plant, ginning outturn, seed index and seed cotton yield whereas lint index was calculated on formula basis. The development of potential hybrids depends on selecting superior parents possessing higher directional dominance, genetic diversity and allelic differences for most of the traits. Of these, the genetic divergence can be estimated by an effective statistical tool, Mahalanobis $\mathrm{D}^{2}$ statistic that gives an estimate about the diverse nature of the parents.

In this experiment genetic diversity was assessed among genotypes consisting of both hybrids and parents, to determine the best possible triple cross hybrids and double cross hybrids as reported by Antonio et al.(2016) in tomato.

\section{Results and Discussion}

The genetic diversity among 35 genotypes was measured by employing $\mathrm{D}^{2}$ statistics and grouped into four clusters using Tocher's method as given by Rao (1952). Distribution of genotypes in each cluster is presented in Table 2 and Figure 1. Similar genetic diversity works were carried out on this crop by Sambamurthy et al. (2004), Satish et al. (2009), Shakthi et al. (2009) and Kulkarni et al. (2011). Cluster I was found largest with 23 genotypes followed by cluster II comprising six genotypes, while cluster III comprised of five genotypes and cluster IV includes a solitary hybrid. The inter-cluster and intracluster $\mathrm{D}^{2}$ values were estimated and have been presented in Table 3. The maximum intra cluster distance was recorded within cluster III (13.91) which had only parents, while it was lowest in cluster IV as it included only one hybrid (CPD-462×SB-YF-425), indicating that the genotypes of these respective clusters might be differing marginally in their genetic architecture.

The maximum inter cluster distance was observed between cluster III and cluster IV (76.21) followed by cluster I and cluster III (42.67). The genotypes belonging to clusters III and cluster IV possess highest inter cluster distance, suggesting that hybridization between the parents of these respective divergent clusters may lead to higher magnitude of heterosis for the characters concerned. Significant level of desired heterosis is achieved whenever parents with moderate divergence are used for crossing. (Arunachalam et al., 1984)

From this exercise it was clear that the lines which were selected for experiment got included in two different clusters, cluster II 
and cluster III, where as all the testers were under the single cluster, i.e cluster III. The inter cluster distance between clusters II and III was considerably high, hence the high yielding hybrids such as CPD-462 $\times$ SB-YF425, FLT-36×SB-YF-425, FLT-31 $\times$ SB-YF425, FLT-31×BCS 23-18-7, CPD-462×BCS 23-18-7 resulted from the parental genotypes from cluster II and III. Similar results were found by Pushpam et al. (2004), Gopinath et al., (2009), and Xian Tao et al., (2011).

Cluster means of 11 yield and yield contributing characters were assessed and are presented in Table 4. The mean comparison of the different characters indicated considerable differences among the clusters for all the characters. The genotypes in cluster II had minimum days to 50 per cent flowering and maximum days to 50 per cent flowering was found in genotypes falling under cluster III. With respect to the trait boll weight, the genotypes possessing highest boll weight fell under cluster II (4.34 g) and genotypes with lowest boll weight fell under cluster III (3.10 g). Tall types were found in cluster II (138.42 $\mathrm{cm})$ and dwarf types in cluster III (120.60 $\mathrm{cm})$. The parental lines possessing less number of monopodia per plant were included under cluster III (1.12) while highest number in cluster II (1.68). The genotypes in cluster I (23.89) had the highest number of sympodia while cluster III (20.53) genotypes had the lowest number. Cluster II (16.91) and cluster
III (6.66) recorded highest and lowest means for the trait total number of bolls per plant, respectively. Genotypes of highest lint index were found to be under cluster III (6.04 g) and lowest under cluster II (10.62 g). The ginning outturn mean values were highest for genotypes falling under cluster II (35.38\%) and lowest in cluster III (33.31\%). Cluster I $(42.22 \mathrm{~cm})$ and cluster II $(38.88 \mathrm{~cm})$ had highest and lowest sympodial length at 50 per cent plant height, respectively. The low seed index genotypes were categorised under cluster II (10.62 g), while highest were under cluster III (11.97 g). The cluster II (948.83 $\mathrm{kg} / \mathrm{ha}$ ) mean for the seed cotton yield is highest where as the genotypes of cluster III (194.24 kg/ha) had lowest mean value. Among 11 characters studied, the genotypes in cluster II had maximum values for boll weight, plant height, number of monopodia per plant, number of bolls per plant, ginning outturn and seed cotton yield. Cluster I had maximum values for number of sympodia per plant, sympodial length at 50 per cent plant height and cluster III had highest mean values for days to 50 per cent flowering, seed index and lint index. Analysis of cluster means indicated substantial variation among the four clusters formed. In the present study clusters I and IV included high yielding hybrids, whereas cluster II and cluster III included parental genotypes. The different genetic make up of parents and hybrids has shown up in differential clustering.

Table.1 Experimental material used in the study

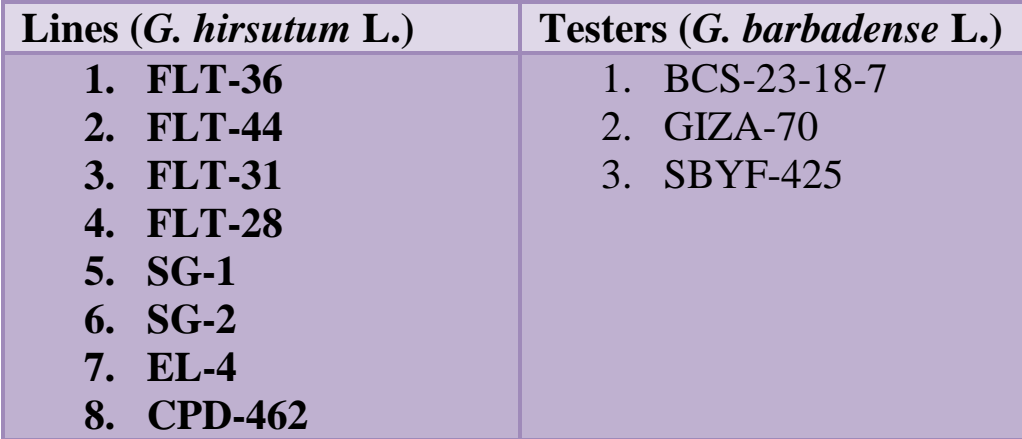


Table.2 Distribution of genotypes into clusters considering both hybrids and parents together

\begin{tabular}{|c|c|c|c|}
\hline Sl. No. & Cluster & $\begin{array}{l}\text { Number of } \\
\text { genotypes }\end{array}$ & Name of genotype \\
\hline 1 & I & 23 & $\begin{array}{l}\text { FLT-36 × BCS-23-18-7, FLT-36 × GIZA-70, FLT-36 × SB-YF-425, FLT-44 × BCS-23-18-7, FLT-44 × GIZA-70, FLT- } \\
44 \times \text { SB-YF-425, FLT-31 × BCS-23-18-7, FLT-31 × GIZA-70, FLT-31 × SB-YF-425, FLT-28 × BCS-23-18-7, FLT-28 } \\
\times \text { GIZA-70, FLT-28 × SB-YF-425, SG-1 × BCS-23-18-7, SG-1 × GIZA-70, SG-1 × SB-YF-425, SG-2 × BCS-23-18-7, } \\
\text { SG-2 × GIZA-70, SG-2 × SB-YF-425, CPD-462 × BCS-23-18-7, CPD-462 × GIZA-70 }\end{array}$ \\
\hline 2 & II & 6 & FLT-36,FLT-31, FLT-28, FLT-33, EL-4, CPD-462 \\
\hline 3 & III & 5 & BCS-23-18-7,GIZA-70,SB-YF-425, SG-1, SG-2 \\
\hline 4 & IV & 1 & CPD-462 $\times$ SB-YF-425 \\
\hline
\end{tabular}

Table.3 Average intra and inter cluster distance values considering both hybrids and parents together

\begin{tabular}{|c|c|c|c|c|}
\hline Clusters & I & II & III & IV \\
\hline I & 7.38 & 24.69 & 42.67 & 22.47 \\
\hline II & & 8.07 & 39.75 & 33.49 \\
\hline III & & & 13.91 & 76.21 \\
\hline IV & & & & 0.00 \\
\hline
\end{tabular}

Table.4 Cluster means considering both hybrids and parents together

\begin{tabular}{|c|c|c|c|c|c|c|c|c|c|c|c|c|c|}
\hline Cluster & $\begin{array}{c}\text { Days to } \\
50 \% \\
\text { flowering }\end{array}$ & $\begin{array}{c}\text { Boll } \\
\text { weight } \\
\text { (g) }\end{array}$ & $\begin{array}{c}\text { Plant } \\
\text { height } \\
\text { (cm) }\end{array}$ & $\begin{array}{c}\text { Number of } \\
\text { monopodia } \\
\text { per plant }\end{array}$ & $\begin{array}{c}\text { Number } \\
\text { of } \\
\text { sympodia } \\
\text { per plant }\end{array}$ & $\begin{array}{c}\text { Number } \\
\text { of bolls } \\
\text { per } \\
\text { plant }\end{array}$ & $\begin{array}{c}\text { Sympodial } \\
\text { length at } 50 \\
\% \text { plant } \\
\text { height }(\mathrm{cm})\end{array}$ & $\begin{array}{c}\text { Ginning } \\
\text { outturn } \\
(\%)\end{array}$ & $\begin{array}{c}\text { Seed } \\
\text { index } \\
(\mathrm{g})\end{array}$ & $\begin{array}{l}\text { Lint } \\
\text { index } \\
(\mathrm{g})\end{array}$ & $\begin{array}{c}\text { Seed } \\
\text { cotton } \\
\text { yield } \\
(\mathrm{kg} / \mathrm{ha})\end{array}$ & $\begin{array}{c}\text { Cluster } \\
\text { score }\end{array}$ & $\begin{array}{c}\text { Cluster } \\
\text { rank }\end{array}$ \\
\hline I & $\begin{array}{c}77.54 \\
(3)\end{array}$ & $\begin{array}{l}3.75 \\
(3)\end{array}$ & $\begin{array}{c}162.20 \\
\text { (1) }\end{array}$ & $\begin{array}{l}1.97 \\
(2)\end{array}$ & $\begin{array}{c}22.92 \\
(2)\end{array}$ & $\begin{array}{c}25.15 \\
(2)\end{array}$ & $\begin{array}{c}50.89 \\
(1)\end{array}$ & $\begin{array}{c}30.50 \\
(4)\end{array}$ & $\begin{array}{c}12.88 \\
(2)\end{array}$ & $\begin{array}{l}5.68 \\
(3)\end{array}$ & $\begin{array}{c}582.05 \\
(3)\end{array}$ & 26 & II \\
\hline II & $\begin{array}{c}78.67 \\
(2)\end{array}$ & $\begin{array}{c}4.24 \\
(1)\end{array}$ & $\begin{array}{c}132.79 \\
(3)\end{array}$ & $\begin{array}{l}1.39 \\
(3)\end{array}$ & $\begin{array}{c}22.72 \\
(4)\end{array}$ & $\begin{array}{c}13.89 \\
(3)\end{array}$ & $\begin{array}{c}41.48 \\
(3)\end{array}$ & $\begin{array}{c}34.60 \\
(1)\end{array}$ & $\begin{array}{c}10.52 \\
(4)\end{array}$ & $\begin{array}{c}5.58 \\
(4)\end{array}$ & $\begin{array}{c}825.66 \\
\text { (2) }\end{array}$ & 30 & III \\
\hline III & $\begin{array}{c}96.00 \\
(1)\end{array}$ & $\begin{array}{c}3.43 \\
(4)\end{array}$ & $\begin{array}{c}127.23 \\
(4)\end{array}$ & $\begin{array}{l}1.14 \\
(4)\end{array}$ & $\begin{array}{c}22.91 \\
(3)\end{array}$ & $\begin{array}{c}8.80 \\
(4)\end{array}$ & $\begin{array}{c}40.89 \\
(4)\end{array}$ & $\begin{array}{c}34.49 \\
(2)\end{array}$ & $\begin{array}{c}11.63 \\
(3)\end{array}$ & $\begin{array}{l}6.16 \\
(1)\end{array}$ & $\begin{array}{c}289.66 \\
(4)\end{array}$ & 34 & IV \\
\hline IV & $\begin{array}{c}77.33 \\
(4)\end{array}$ & $\begin{array}{l}4.07 \\
(2)\end{array}$ & $\begin{array}{c}158.07 \\
\text { (2) }\end{array}$ & $\begin{array}{l}2.36 \\
(1)\end{array}$ & $\begin{array}{c}24.13 \\
(1)\end{array}$ & $\begin{array}{c}34.00 \\
(1)\end{array}$ & $\begin{array}{c}48.55 \\
(2)\end{array}$ & $\begin{array}{l}31.70 \\
(3)\end{array}$ & $\begin{array}{c}12.95 \\
(1)\end{array}$ & $\begin{array}{l}6.01 \\
(2)\end{array}$ & $\begin{array}{c}1239.38 \\
\text { (1) }\end{array}$ & 20 & I \\
\hline
\end{tabular}


Table.5 Per cent contribution of characters towards divergence

\begin{tabular}{|c|l|c|}
\hline Sl. No. & \multicolumn{1}{|c|}{ Characters } & $\begin{array}{c}\text { Characters contribution (\%) considering } \\
\text { both parents and hybrids }\end{array}$ \\
\hline $\mathbf{1}$ & Days to 50 \% flowering & 22.86 \\
\hline $\mathbf{2}$ & Plant height & 7.23 \\
\hline $\mathbf{3}$ & Boll weight & 0.34 \\
\hline $\mathbf{4}$ & Number of monopodia per plant & 8.24 \\
\hline $\mathbf{5}$ & Number of sympodia per plant & 0.50 \\
\hline $\mathbf{6}$ & Number of bolls per plant & 12.10 \\
\hline $\mathbf{7}$ & Sympodial length at 50 \% plant & 2.69 \\
\hline $\mathbf{8}$ & height & 2.18 \\
\hline $\mathbf{9}$ & Ginning outturn & 17.82 \\
\hline $\mathbf{1 0}$ & Lint index & 0.67 \\
\hline $\mathbf{1 1}$ & Seed index & 25.38 \\
\hline
\end{tabular}

Fig.1 Cluster grouping considering parents and hybrids using Tocher method

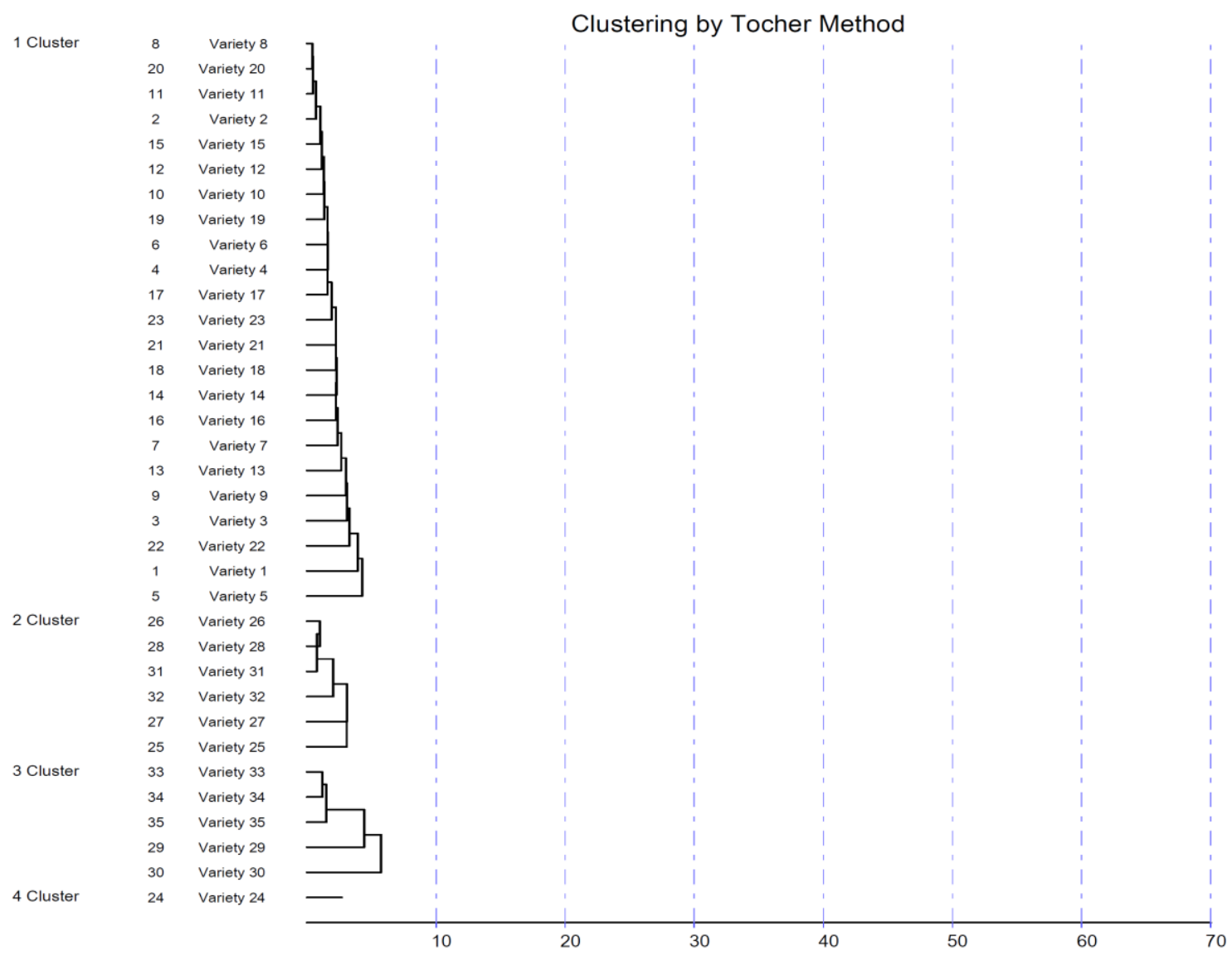


All 36 genotypes spread over 6 clusters were scored based on their means across the clusters for all the 13 characters, as given in Table 4. The highest cluster mean with respect to particular character was given the first rank and next cluster possessing next best means were given 2nd, 3rd and so on up to 6th rank for all the traits. Finally, the clusters are ranked based on the overall score obtained from 13 characters. The lowest scoring cluster was given the first rank, and next cluster possessing the score above the previous ones were given 2nd, 3rd and so on up to 6th rank. Accordingly, cluster IV with an overall score of 20 across the 13 characters elected the first rank followed by cluster I, II and III, indicating presence of most promising genotypes in them and further breeding programme to generate new material. Cluster III stood highest with an overall score of 34 . Similar work was reported by Bhaganna et $a l .$, (2017) in French bean.

The contribution of various characters towards diversity is given in Table 5. Among eleven characters studied, seed cotton yield $(25.38 \%)$ and days to 50 per cent flowering (22.86\%), contributed high for divergence while other characters like boll weight $(0.34$ $\%)$, number of sympodia per plant $(0.5 \%)$ and lint index $(0.67 \%)$ contributed very little for divergence. The contribution of other traits include plant height $(7.23 \%)$, number of monopodia per plant $(8.24 \%)$, number of bolls per plant $(12.10 \%)$, sympodial length at 50 per cent plant height $(2.69 \%)$, ginning outturn $(2.18 \%)$ and lint index $(17.82 \%)$. Among the eleven characters studied, the maximum contribution to the total divergence was by seed cotton yield followed by number of bolls per plant and lint index. The above results imply that in order to select genetically diverse hybrids, selection strategy should be based on the traits like seed cotton yield, number of bolls per plant and lint index. De et al. (1988) stated that traits contributing maximum towards the $\mathrm{D}^{2}$ values needed to be given more emphasis for deciding the clusters to be taken for the purpose of choice of parents for hybridization.

In concluded as the inter-cluster distance was found to be highest between clusters III and IV, hence, it could be expected that the cross combinations involving hybrid in solitary cluster IV and best parents of cluster III could be used to develop triple cross hybrids for future breeding programs. Since hybrid CPD$462 \times$ SB-YF-425 formed a solitary cluster (IV) apart from remaining 23 hybrids in cluster (I), it could indicate an opportunity for developing best double cross hybrids involving CPD-462 $\times$ SB-YF-425 with any good hybrid of cluster I. Similar result was reported by Antonio et al. (2016).

\section{References}

Anonymous, 2018, Annu. Rep. ICAR - All India Coordinated Research Project on cotton, 14(1): 2-5.

Antonio, T., Marcelo, V., Alexandre, P. and Rosana, R., 2016, Prospecting of tomato hybrids for table and industry via mixed modeling and multivariate analysis. Hortic. bras., 35: 20-25.

Arunachalam, V., Bandopadhya, A., Nigam, S. N. and Gibbons, R. W., 1984, Heterosis in relation to genetic divergence and specific combining ability in groundnut (Arachis hypogaea L.). Euphyt., 33: 33-39.

Bhaganna, H., Salimath, P. M., Aghora, TS., Nagarajappa, A. and Ganga Prasad S., 2017, Genetic Diversity analysis by D2 clustering of yield and yield attributing traits in French bean (Phaseolus vulgaris L.). J. Pharmacogn Phytochem.,6(6): 13311335

De, R. N., Seetharaman, R., Sinha, M.T. and Banerjee, S.P. 1988. Genetic 
divergence in rice. Indian $J$ Genet Plant Breed., 48 : 189-194.

Gopinath, M., Rajamani, S., Krishna Naik, R. and Mallikarjuna R. C., 2009, Genetic divergence for lint characters for upland cotton (Gossypium hirsutum L.). J. Cotton Res. Dev., 23 (1): 46-48.

Kulkarni, A. A., Nanda, H. C. and Patil, S. G., 2011, Studies on genetic divergence in upland cotton (Gossypium hirsutum L.). J. cotton Res. Dev., 25 (1): 9-13.

Mahalanobis, P. C., 1936, A statistical study at Chinese head measurement. J. Asiatic Sco. Bengal., 25: 301-377.

Pushpam, R., Raveendran, T. S., Devasena, N. and Ravikesavan, R., 2004, Studies on genetic diversity in upland cotton (Gossypium hirsutum) J. Indian Soc. Cotton Improv., 29 (2): 135-143.

Rao, C. R., 1952, Advanced Statistical Methods in Biometrical Research, John Wiley \& Sons. Inc., New York, pp. 357-363.

Sambamurthy, J. S. V., Chamundeswari, N. and Udagasree, P., 2004, Studies on genetic divergence in introgressed lines of upland cotton (Gossypium hirsutum L.). Paper presented in: Int. Symp. Strat. Sust. Cotton Prod. - A Global Vision. 1. Crop Improv., 23-25 November, 2004, held at Uni. Agric. Sci., Dharwad, pp. 125-129.

Satish, Y., Jain, P. P. and Chhabra, B. S., 2009 , Studies on genetic diversity in upland cotton (G. hirsutum L.). J. Cotton Res. Dev., 23 (1): 18-22.

Shakthi. A. R., Kumar, M. and Ravikesavan. R., 2009, Genetic diversity in cotton (G. hirsutum L.). Adv. Plant Sci., 22(1): 285-291.

XianTao, A., XueYuan, L., JunDuo W., JuYun, Z., Hong, S., Tuerxunjiang., LiKun, D. and Ming, M., 2011, Genetic diversity of agronomic phenotypes in upland cotton varieties of north Xinjiang area. Mol. Plant. Breed., 9 (1): 113-122.

\section{How to cite this article:}

Malathi, S. and Rajesh S. Patil. 2019. Genetic Diversity Studies on Parental and Interspecific Hybrids (Gossypium hirsutum L. $\times$ Gossypium barbadense L.) of Cotton. Int.J.Curr.Microbiol.App.Sci. 8(04): 263-269. doi: https://doi.org/10.20546/ijcmas.2019.804.029 